\title{
Suggestive Evidence of a Locus on Chromosome 10p Using the NIMH Genetics Initiative Bipolar Affective Disorder Pedigrees
}

Tatiana Foroud, ${ }^{1 *}$ Peter F. Castelluccio, ${ }^{1}$ Daniel L. Koller, ${ }^{1}$ Howard J. Edenberg, ${ }^{1}$ Marvin Miller, ${ }^{1}$ Elizabeth Bowman, ${ }^{1}$ N. Leela Rau, ${ }^{1}$ Carrie Smiley, ${ }^{1}$ John P. Rice, ${ }^{2}$ Alison Goate, ${ }^{2}$ Christopher Armstrong, ${ }^{2}$ Laura J. Bierut, ${ }^{2}$ Theodore Reich, ${ }^{2}$ Sevilla D. Detera-Wadleigh, ${ }^{3}$ Lynn R. Goldin, ${ }^{3 b}$ Judith A. Badner, ${ }^{3 a}$ Juliet J. Guroff, ${ }^{3}$ Elliot S. Gershon, ${ }^{3 a}$ Francis J. McMahon, ${ }^{4 a}$ Sylvia Simpson, ${ }^{4}$ Dean MacKinnon, ${ }^{4}$ Melvin McInnis, ${ }^{4}$ O. Colin Stine, ${ }^{4 \mathrm{c}}$ J. Raymond DePaulo, ${ }^{4}$ Mary C. Blehar, ${ }^{5}$ and John I. Nurnberger, Jr., ${ }^{6}$

${ }^{1}$ Department of Medical and Molecular Genetics, Indiana University School of Medicine, Indianapolis, Indiana

${ }^{2}$ Department of Psychiatry, Washington University School of Medicine, St. Louis, Missouri

${ }^{3}$ Clinical Neurogenetics Branch, National Institute of Mental Health, National Institutes of Health, Bethesda, Maryland

${ }^{4}$ Department of Psychiatry, Johns Hopkins University Medical School, Baltimore, Maryland

${ }^{5}$ Mood, Anxiety, and Personality Disorders Research Branch, National Institute of Mental Health, National Institutes of Health, Rockville, Maryland

${ }^{6}$ Department of Psychiatry, Indiana University School of Medicine, Indianapolis, Indiana

As part of a four-center NIMH Genetics Initiative on Bipolar Disorder, a genome screen using 365 markers was performed on 540 DNAs from 97 families, enriched for affected relative pairs. This is the largest uniformly ascertained and assessed linkage sample for this disease, and includes 232 subjects diagnosed with bipolar I (BPI), 32 with schizo-affective, bipolar type (SABP), 72 with bipolar II (BPII), and 88 with unipolar recurrent depression (UPR). A hierarchical set of definitions of affected status was examined. Under Model I, affected individuals were those with a diagnosis of BPI or SABP, Model II included as affected those fitting Model I plus BPII, and Model III included those fitting Model II plus UPR. This

Contract grant sponsor: NIMH; Contract grant numbers: U01 MH46282, U01 MH54794, U01 MH46280, U01 MH54723, U01 MH46274, and U01 MH54701.

aPresent address: Department of Psychiatry, Biological Sciences Division, University of Chicago, Chicago, IL.

${ }^{b}$ Present address: Genetic Epidemiology Branch, DCEG, NCI, Bethesda, MD.

cPresent address: Center for the Genetics of Asthma and Complex Diseases, School of Medicine, University of Maryland, Baltimore, MD.

*Correspondence to: Tatiana Foroud, Ph.D., Department of Medical and Molecular Genetics, Indiana University School of Medicine, 975 W. Walnut Street IB-155, Indianapolis, IN 46202. E-mail: tforoud@iupui.edu

Received 30 July 1999; Accepted 26 August 1999 data set was previously analyzed using primarily affected sib pair methods. We report the results of nonparametric linkage analyses of the extended pedigree structure using the program Genehunter Plus. The strongest finding was a lod score of 2.5 obtained on chromosome 10 near the marker D10S1423 with diagnosis as defined under Model II. This region has been previously implicated in genome-wide studies of schizophrenia and bipolar disorder. Other chromosomal regions with lod scores over 1.50 for at least one Model Included chromosomes 8 (Model III), 16 (Model III), and 20 (Model I). Am. J. Med. Genet. (Neuropsychiatr. Genet.) 96:1823, 2000 ๑ 2000 Wiley-Liss, Inc.

KEY WORDS: bipolar affective disorder; genetics; linkage; nonparametric analysis; genomic survey

\section{INTRODUCTION}

Bipolar affective disorder (BP) is a disabling condition involving dysregulation of multiple physiologic functions, including mood, appetite, sleep, and activity [Goodwin and Jamison, 1990]. It occurs in about 1\% of the population, usually with onset in early adulthood. BP has been observed to aggregate within families [Nurnberger et al., 1994b], with evidence from twin and adoption studies suggesting a significant genetic contribution to risk [Bertelsen et al., 1977; Mendlewicz 
and Rainer, 1977]. Segregation analysis has not been consistent with a single gene mode of inheritance [Nurnberger et al., 1994b] for the majority of bipolar cases.

Initial studies to identify the genetic loci underlying bipolar disorder relied initially on large pedigrees with multiple affected individuals who appeared to share a gene with major effect. These extended families typically had patients diagnosed not only with bipolar I (BPI), the most severe form of the disorder, but also bipolar II (BPII), a less severe, but clinically related entity. Some studies expanded the diagnostic criteria to also include unipolar recurrent depression (UPR). Perhaps in part due to the varied clinical diagnoses and genetic models used in these studies of principally large, extended families, linkage to chromosomes 11 [Egeland et al., 1987], 18p [Berrettini et al., 1994; Detera-Wadleigh et al., 1999; Nothen et al., 1999], 18q [DeBruyn et al., 1995; Freimer et al., 1996; McMahon et al., 1997; Stine et al., 1995], and 21q [Aita et al., 1999; Detera-Wadleigh et al., 1996; Kwok et al., 1999; Straub et al., 1994] were reported. Additional studies also identified linkage to chromosomes 4 [Ewald et al., 1998b; Nothen et al., 1997], 5 [Coon et al., 1993], and 12 [Barden et al., 1998; Ewald et al., 1998a].

More recently, a large collection of uniformly ascertained and assessed families with individuals diagnosed with bipolar disorder was assembled as part of the NIMH Genetics Initiative. From these families, an initial genome screening set was selected that consisted primarily of affected sib pairs and their parents, but also included other relatives affected with bipolar disorder. In order to maximize the utility of the sample for genetic analyses, affected status was defined by three hierarchical models. The strictest Model Included as affected only those individuals diagnosed with BPI or SABP. Model II included individuals with a Model I diagnosis as well as BPII individuals. The broadest model (Model III) included individuals with a Model II diagnosis as well as UPR. Initial analysis of these pedigrees focused primarily on affected sib pair methods [Edenberg et al., 1997; Detera-Wadleigh et al., 1997; Rice et al., 1997; Stine et al., 1997].

Linkage analyses using single-point and multipoint sib pair methods identified several chromosomal regions of interest that appeared promising in the initial genome screen. Possible evidence of linkage to chromosomes 1, 7q, 10p, 16p, and 22 was reported [Edenberg et al., 1997; Detera-Wadleigh et al., 1997; Rice et al., 1997; Stine et al., 1997). Interestingly, despite numerous previous reports of linkage to chromosome 18p and $18 \mathrm{q}$ in other studies, the NIMH Genetics Initiative collection of pedigrees did not demonstrate significant evidence of linkage to any part of chromosome 18 [DeteraWadleigh et al., 1997]. Only one marker (D18S70) reached nominal significance, $P<0.05$, under any of our three hierarchical affectation models. In addition, previous reports of linkage to chromosomes 4, 5, 11, and 12 were not replicated [Edenberg et al., 1997; Detera-Wadleigh et al., 1997; Rice et al., 1997; Stine et al., 1997]. Modest evidence of linkage to chromosome 21q in a similar region to that reported previously [Detera-
Wadleigh et al., 1996] was found in this data set, with the most significant result obtained near the marker D21S65.

In order to optimally utilize the genetic information in the NIMH Genetics Initiative pedigrees, which included a large number of affected relative pairs other than sib pairs, a genome-wide analysis was performed using the complete pedigree structures. Recently, Kong and Cox [1997] have demonstrated that the extended pedigree methods developed by Kruglyak et al. [1996] and implemented in the Genehunter program can be overly conservative when genotypic data are missing. Our initial genotyped sample included intermediate relatives whenever possible, but marker genotypes were missing for some individuals who were unwilling or unable to participate. Therefore, we have employed a modified version of Genehunter, developed by Kong and Cox [1997]. This analysis continues to support linkage to chromosome $10 \mathrm{p}$ in the region near the marker D10S1423 with a lod score of 2.5 under the intermediate hierarchical model of disease, Model II.

\section{SUBJECTS AND METHODS Family Ascertainment and Evaluation}

The NIMH Genetics Initiative for bipolar disorder included four sites: Indiana University (John Nurnberger, PI), Johns Hopkins University (Raymond DePaulo, PI), the NIMH Intramural Research Program (Elliot Gershon, PI), and Washington University at St. Louis (Theodore Reich, PI). Bipolar (BP) families were ascertained using the following criteria: (a) the proband must have bipolar I disorder (BPI) and be admitted to one of the screening treatment centers; (b) a second affected first-degree relative must be available, with either BPI or schizoaffective bipolar type disorder (SABP); and (c) either the proband or secondary affected relative must have at least 2 living sibs 18 years of age or older. The proband must not be the offspring of a bilineal mating, which was defined as both parents diagnosed with BPI or SABP.

All subjects were assessed using the Diagnostic Instrument for Genetic Studies (DIGS) [Nurnberger et al., 1994a] and the Family Interview for Genetic Studies (FIGS) for information about relatives. Medical records were requested for all instances of inpatient and outpatient psychiatric treatment. Final diagnoses were made independently by two clinician-reviewers using a best-estimate procedure, combining all available information.

A set of three hierarchical diagnoses was used in all analyses. Under Model I, an affected individual was one who was diagnosed with either SABP or BPI. Under Model II, affected individuals were those included with SABP, BPI, and BPII. Under Model III, affected individuals were those with SABP, BPI, and BPII, as well as UPR.

\section{Genotyping Sample}

By spring 1995, approximately 140 families containing 1,200 subjects had been ascertained, and the data were reviewed in order to select a subset of individuals 
to be genotyped as part of the initial genome screen. A series of rules was developed in order to genotype a consistent sample of individuals composed mainly of affected sib pairs, but that would also allow for analysis of other types of affected relative pairs. Intervening relatives were genotyped, whenever possible, in order to increase the power to estimate identity by descent (IBD) among all affected relative pairs. Five hundred forty subjects were chosen from 97 families. This initial sample was composed primarily of affected individuals, with individuals considered affected if they met the requirements of any of the three hierarchical models.

The final genotyping sample contained 264 individuals with Model I diagnoses comprising 121 Model I sib pairs and 227 Model I relative pairs. Seventy individuals were diagnosed with BPII yielding a total of 197 Model II sib pairs and 324 Model II affected relative pairs. Finally, 88 individuals were diagnosed with UPR and together with the other individuals considered affected under Model III produced 282 affected sib pairs and 412 affected relative pairs. All of the above pair counts were calculated using all possible pairs of affected relatives from families with at least 2 affected individuals; however, these counts do not include parent-offspring pairs because they do not provide linkage information.

\section{Genotyping}

DNA from the genotyping sample was distributed to the laboratories at the four sites. The genome was divided among the four laboratories by chromosome. Genotyping, error detection, allele frequency estimation, and marker map construction were as described previously [Edenberg et al., 1997; Detera-Wadleigh et al., 1997; Rice et al., 1997; Stine et al., 1997]. A total of 319 markers was genotyped in the sample of 540 individuals. The average distance between markers was $9.9 \mathrm{cM}$, with the markers averaging 9.8 alleles each and an average heterozygosity of $74 \%$. Following an initial genome screen [Edenberg et al., 1997; DeteraWadleigh et al., 1997; Rice et al., 1997; Stine et al., 1997], additional markers were genotyped in the laboratories at Washington University and Indiana University. The results presented here include 46 markers not previously published on chromosomes $1,5,6,8,10$, 12,15 , and 17. These were either additional markers genotyped in regions of interest identified as part of the initial analyses or were in regions with larger intermarker distances.

\section{Statistical Methods}

Linkage analysis was primarily focused on nonparametric affected relative pair methods since the results of affected sib pair analyses have been published previously [Edenberg et al., 1997; Detera-Wadleigh et al., 1997; Rice et al., 1997; Stine et al., 1997]. We utilized a model-free pedigree analysis approach (Genehunter) proposed by Kruglyak et al. [1996], which examines the extent of allele sharing by descent among all affected relatives rather than simply affected sib pairs. Analyses were performed examining all affected individuals simultaneously. Recently, Genehunter has been shown to be unacceptably conservative due to the overestimation of the variance of the statistic when the identity by descent information is incomplete [Kong and Cox, 1997]. Because families collected for most complex disease studies are incomplete, the resulting loss of power can be quite dramatic. We utilized a modified program proposed by Kong and Cox [1997], Genehunter-Plus, that does not severely overestimate the $P$ value associated with the test statistic.

\section{RESULTS}

The strongest finding in this data set was a lod score of 2.5 obtained on chromosome 10 near the marker D10S1423, using diagnostic Model II. The chromosomal region with evidence for linkage also included the marker D10S1426. In this region, the Model I lod score was 1.5 and the Model III lod score was 1.3 (Fig. 1). Four other regions had lod scores over 1.50 under at least one of the three models (Table 1). The marker D8S1106 on chromosome 8 had a lod score of 1.6 under Model III with a slightly lower lod score of 1.4 under Model II. On chromosome 16, Model III had a lod score of 1.7 near the marker D16S749. Finally, the marker D20S173 had a lod score of 1.7 under Model I at the q-terminus of chromosome 20.

Linkage to chromosome 10 has also been reported in several studies of schizophrenia, utilizing primarily Caucasian samples. Because we identified linkage to chromosome 10 in a sample of mixed ethnicity, allele frequencies were recalculated for the chromosome 10 markers in the critical region using only those families reporting themselves to be Caucasian, non-Hispanic (91 of 97 families). The linkage analysis was then repeated using the race-specific allele frequencies in this reduced sample of 91 Caucasian, non-Hispanic families. The maximum lod score under Model II was 2.3 and remained at the marker D10S1423. The maximum lod scores for Models I and II were both 1.20 at or very near the marker D10S1423.

Recently, Badner and colleagues [1998] have shown that for traits determined by multiple loci in which one

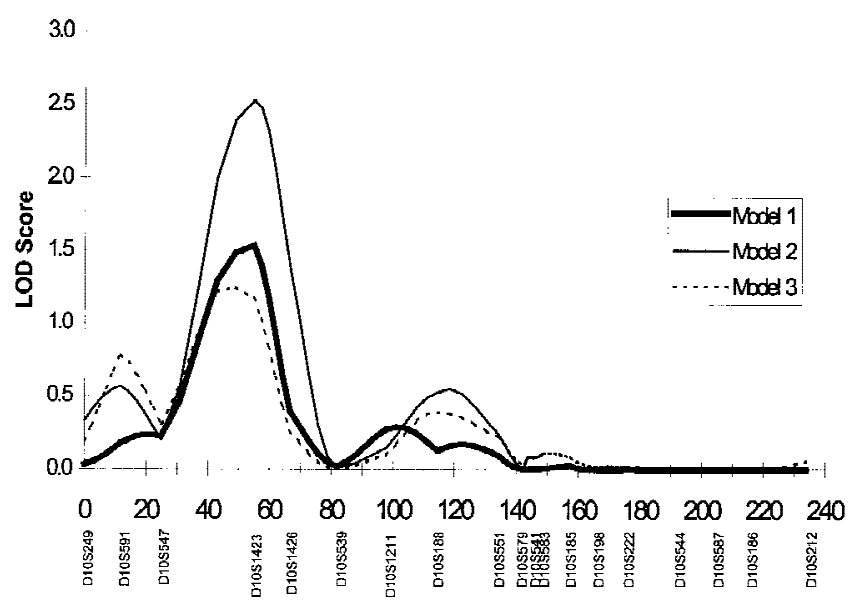

Fig. 1. Multipoint lod scores for chromosome 10 markers for all models. 
TABLE I. Summary of Genome-Wide Linkage Results*

\begin{tabular}{ccccc}
\hline Chromosome & Marker & Model I & Model II & Model III \\
\hline 8 & D8S1106 & 0.1 & 1.4 & $\mathbf{1 . 6}$ \\
10 & D10S1423 & $\mathbf{1 . 5}$ & $\mathbf{2 . 5}$ & 1.3 \\
16 & D16S749 & 0.6 & 1.2 & $\mathbf{1 . 7}$ \\
20 & D20S173 & $\mathbf{1 . 7}$ & 0.5 & 0.4 \\
\hline
\end{tabular}

*For any markers with lod scores over 1.5 for any model, the data are shown for all models.

or more of the trait-influencing genes has a common susceptibility allele(s), it may be more powerful to analyze nuclear families rather than extended pedigrees with multiple affected individuals. Therefore, we have also performed the analyses limiting the data set to only nuclear pedigrees. These more conservative analyses confirmed that the highest lod score in the genome screen sample was on chromosome $10(\operatorname{lod}=1.8)$ near the marker D10S1423.

\section{DISCUSSION}

Previous analyses using primarily affected sib pair methods in this same data set had identified a series of chromosomal regions with interesting, although not highly significant results [Edenberg et al., 1997; Detera-Wadleigh et al., 1997; Rice et al., 1997; Stine et al., 1997]. As with many complex diseases, the literature in bipolar illness has reported linkage to numerous chromosomal regions with many findings not replicated or replicated in only some but not all studies [Risch and Botstein, 1996]. Likely sources for these discordant results include genetic heterogeneity, oligogenic inheritance, insufficient power, and type II error.

In these analyses, we report the results from the same families now analyzed using genotypic and phenotypic data from the extended pedigrees. In many regions with interesting initial linkage results, additional markers have been genotyped. The strongest result in this analysis of 97 families was the lod score of 2.5 on chromosome 10 near the marker D10S1423 under Model II. This finding would meet the criteria proposed by Lander and Kruglyak [1995] for suggestive (lod > 2.2) but not significant (lod > 3.6) linkage. Of interest, in the previous affected sib pair analyses [Rice et al., 1997] the marker D10S1423 was also significant under both Model I and Model II with marker allele sharing estimated at $57 \%, P<0.01$. In addition, the MOD score, or maximum lod score using the extended pedigree structure and assuming a single diallelic locus, under Model II was 3.40, $P<0.01$; the MOD score was also significant under Models I, 2.04; $P<0.025$, and III, 1.77; $P<0.05$.

Our Model II gave the highest lod score in these analyses and includes persons affected with BPII disorder, which we have defined as recurrent unipolar depression plus hypomania, by RDC criteria [NIMH Genetics Initiative Bipolar Group, 1997]. It may be that, for this susceptibility locus, expanding the model to include recurrent unipolar depression without hypomania (Model III) results in the inclusion of individuals who are phenocopies and thus reduces the linkage evidence [see also Nurnberger et al., 1994b].

In the previous sib pair linkage analysis [Rice et al.,
1997], a second region on chromosome 10 had stronger evidence of linkage to the Model II phenotype than the region around D10S1423. This other region on chromosome $10 \mathrm{q}$ had a lod score of approximately 2.0 near the marker D10S188. With the additional markers genotyped in this chromosomal region, and more accurate marker maps estimated, the evidence for linkage to this second region is substantially reduced, with maximum lod scores under all three hierarchical models below 0.75 .

The region of chromosome 10p implicated here has recently been linked to a schizophrenia locus in several genome-wide studies [Faraone et al., 1998; Schwab et al., 1998; Straub et al., 1998]. Using the 43 European American NIMH Genetics Initiative schizophrenia nuclear families, Faraone et al. [1998] found suggestive evidence of linkage to D10S1423, $P=0.0004$, and the adjacent marker D10S582, $P=0.0006$. A large panel of Irish schizophrenia families [Straub et al., 1998] also demonstrated evidence of linkage to this region, with a maximum multipoint $\mathrm{H}-\mathrm{LOD}$ of $1.91, P=0.006$, at the marker D10S2443. Multipoint nonparametric analysis also supported linkage to this region of chromosome $10 \mathrm{p}, P=0.03$. Affected sib pair analyses of a third series of families ascertained in Germany also supported linkage of schizophrenia to $10 \mathrm{p}$ with the greatest evidence at markers D10S582, $P=0.0058$, and D10S1423, $P=0.029$.

Because rates of unipolar depression are higher among relatives of schizophrenia probands in the studies of Gershon et al. [1988] and Maier et al. [1993], and higher rates of schizophrenia have been reported among relatives of probands with schizoaffective disorder in some studies [Gershon et al., 1982; Kendler et al., 1986] there may be common susceptibility loci for both disorders. Linkage to chromosome 10p has been reported in both bipolar and schizophrenia studies. Such consistent linkage findings, often with the same marker, D10S1423, suggest a locus with pleiotropic effects, which in some families result in affective disorder and in others schizophrenia.

Further mapping of the chromosome $10 \mathrm{p}$ region in both bipolar and schizophrenia samples is critical in order to elucidate the gene(s) underlying these disorders. Genotyping and analysis of a replication data set of approximately 360 individuals from bipolar families is currently under way. This will provide an opportunity to further evaluate evidence of linkage to chromosome $10 \mathrm{p}$ in an independent sample. If linkage is present, the families from the two data sets can be used for additional genotyping in order to further localize a potential susceptibility gene in this chromosomal region. 


\section{ACKNOWLEDGMENTS}

This work was supported by cooperative agreements between the sites and the NIMH (National Institute of Mental Health grants U01 MH46282, U01 MH54794, U01 MH46280, U01 MH54723, U01 MH46274, and U01 MH54701).

\section{REFERENCES}

Aita VM, Liu J, Knowles JA, Terwilliger JD, Baltazar R, Grunn A, Loth JE, Kanyas K, Lerer B, Endicott J, Wang Z, Penchaszadeh G, Gilliam TC, Baron M. 1999. A comprehensive linkage analysis of chromosome 21q22 supports prior evidence for a putative bipolar affective disorder locus. Am J Hum Genet. 64:210-217.

Badner JA, Gershon ES, Goldin LR. 1998. Optimal ascertainment strategies to detect linkage to common disease alleles. Am J Hum Genet 63:880-888

Barden N, Morissette J, Shink E, Rochette D, Gagne B, Bordeleau L, Villeneuve A, Sher A, Shaw S, Hopkins P, Sherrington R. 1998. Confirmation of bioplar affective disorder susceptibility locus on chromosome 12 in the region of the Darier disease gene. Am J Med Genet 81:475.

Berrettini WH, Ferraro TN, Goldin LR, Weeks DE, Detera-Wadleigh SD, Nurnberger JI, Gershon ES. 1994. Chromosome 18 DNA markers and manic-depressive illness: evidence for a susceptibility gene. Proc Natl Acad Sci USA 91:5918-5921.

Bertelsen A, Harvald B, Hauge M. 1977. A Danish twin study of manicdepressive disorders. Br J Psychiatry 130:330-351.

Boehnke M. 1991. Allele frequency estimation from data on relatives. Am J Hum Genet 48:22-25.

Coon H, Jensen S, Hoff M, Holik J, Plaetke R, Reimherr F, Wender P, Leppert M, Byerley W. 1993. A genome-wide search for genes predisposing to manic depression, assuming autosomal dominant inheritance. Am J Hum Genet 52:1234-1249.

DeBruyn A, Souery D, Mendelbaum K, Mendlewicz J, Van Broeckhoven C. 1995. Positive linkage results with 18q21.33-q23 markers in a bipolar II family. Psychiatr Genet 5:S16.

Detera-Wadleigh SD, Badner JA, Berrettini WH, Yoshikawa T, Goldin LR, Turner G, Rollins DY, Moses T, Sanders AR, Karkera JD, Esterling LE, Zeng J, Ferraro TN, Guroff JJ, Kazuba D, Maxwell ME, Nurnberger JI Jr, Gershon ES. 1999. A high-density genome scan detects evidence for a bipolar-disorder susceptibility locus on 13q32 and other potential loci on 1q32 and 18p11.2. PNAS 96:5604-5609.

Detera-Wadleigh SD, Badner JA, Goldin LR, Berrettini WH, Sanders AR, Rollins DY, Turner G, Moses T, Haerian H, Muniec D, Nurnberger JI Jr, Gershon ES. 1996. Affected-sib-pair analyses reveal support of prior evidence for a susceptibility locus for bipolar disorder on 21q. Am J Hum Genet 58:1279-1285.

Detera-Wadleigh SD, Badner JA, Yoshikawa T, Sanders AR, Goldin LR, Turner G, Rollins DY, Moses T, Guroff JJ, Kazuba D, Maxwell ME, Edenerg HJ, Foroud T, Lahiri D, Nurnberger JI, Stine OC, McMahon F, Meyers DA, MacKinnon D, Simpson S, McInnis M, DePaulo JR, Rice J, Goate A, Reich T, Blehar MC, Gershon ES. 1997. Initial Genome Scan of the HIMH Genetics Initiative Bipolar Pedigrees: chromosomes 4, 7, 9, 18, 20, and 21q. Am J Med Genet 74:254-262.

Edenberg HJ, Foroud T, Conneally PM, Sorbel JJ, Carr K, Crose C, Willig C, Zhao J, Miller M, Bowman E, Mayeda A, Rau NL, Smiley C, Rice JP, Goate A, Reich T, Stine OC, McMahon F, DePaulo JR, Meyers D, Detera-Wadleigh SD, Goldin LR, Gershon ES, Blehar MC, Nurnberger JI Jr. 1997. Initial genomic scan of the NIMH genetics initiative bipolar pedigrees: chromosomes 3, 5, 15, 16, 17, and 22. Am J Med Genet 74:238-246.

Egeland JA, Gerhard DS, Pauls DL, Sussex JN, Kidd KK, Allen CR, Hostetter AM, Housman DE. 1987. Bipolar affective disorders linked to DNA markers on chromosome 11. Nature 325:783-787.

Ewald H, Degn B, Mors O, Kruse TA. 1998. Significant linkage between bipolar affective disorder and chromosome 12q24. Psychiatr Genet 8: 131-140.

Ewald H, Degn B, Mors O, Kruse TA. 1998. Support for the possible locus on chromosome $4 \mathrm{p} 16$ for bipolar affective disorder. Mol Psychiatry 3 $442-448$.

Faraone SV, Matise T, Svrakic D, Pepple J, Malaspina D, Suarez B, Hampe C, Zambuto CT, Schmitt K, Meyer J, Markel P, Lee H, HarkavyFriedman J, Kaufmann C, Cloninger CR, Tsuang MT. 1998. Genome scan of European American schizophrenia pedigrees: results of the NIMH Genetics Initiative and Millennium Consortium. Am J Med Genet 81:290-295.

Freimer NB, Reus VL, Escamilla MA, McInnies LA, Spesny M, Leaon P, Service SK, Smith LB, Silva S, Rojas E, Gallegos A, Meza L, Fournier E, Baharloo S, Blankenship K, Tyler DJ, Batki S, Vinogradov S, Weissenbach J, Barondes SH, Sandkuijl LA. 1996. Genetic mapping using haplotype, association, and linkage methods suggests a locus for severe bipolar disorder (BPI) at 18q22-q23. Nat Genet 12:436-441.

Gershon ES, DeLisi LE, Hamovit J, Nurnberger JI Jr, Maxwell ME, Schreiber J, Dauphinais D, Dingman W II, Guroff JJ. 1988. A controlled family study of chronic psychoses. Arch Gen Psychiat 45:328336 .

Gershon ES, Hamovit J, Guroff JJ, Dibble E, Leckman JF, Sceery W, Targum SD, Nurnberger JI Jr, Goldin LR, Bunney WE. 1982. A family study of schizoaffective, bipolar i, bipolar ii, unipolar, and normal control probands. Arch Gen Psychiat 39:1157-1167.

Goodwin FK, Jamison KR . 1990. Manic Depressive Illness. New York: Oxford University Press.

Kendler KS, Gruenberg AM, Tsuang MT. 1986. A DSM-III family study of the nonschizophrenic psychotic disorders. Am J Psychiat 143:10981105 .

Kong A, Cox NJ. 1997. Allele-sharing models: LOD scores and accurate linkage tests. Am J Hum Genet 61:1179-1188.

Kruglyak L, Daly MJ, Reeve-Daly MP, Lander ES. 1996. Parametric and nonparametric linkage analysis: a unified multipoint approach. Am J Hum Genet 58:1347-1363.

Kwok JB, Adams LJ, Salmon JA, Donald JA, Mitchell PB, Schofield PR. 1999. Nonparametric simulation-based statistical analyses for bipolar affective disorder locus on chromosome 21q22.3. Am J Med Genet 88: 99-102.

Lander ES, Kruglyak L. 1995. Genetic dissection of complex traits: guidelines for interpreting and reporting linkage results. Nat Genet 11:241247.

Maier W, Lichtermann D, Jurgen M, Hallmayer J, Huen R, Benkert O, Levinson DF. 1993. Continuity and discontinuity of affective disorders and schizophrenia: results of a controlled family study. Arch Gen Psychiat 50:871-883.

McMahon FJ, Hopkins PJ, Xu J, McInnis MG, Shaw S, Cardon L, Simpson SG, MacKinnon DF, Stine OC, Sherrington R, Meyers DA, DePaulo JR. 1997. Linkage of bipolar affective disorder to chromosome 18 markers in a new pedigree series. Am J Hum Genet 61:1397-1404.

Mendlewicz J, Rainer, JD. 1977. Adoption study supporting genetic transmission in manic-depressive illness. Nature 268:327-329.

NIMH Genetics Initiative Bipolar Group. 1997. Genomic survey of bipolar illness in the NIMH genetics initiative pedigrees: a preliminary report. Am J Med Genet 74:227-237.

Nothen MM, Cichon S, Franzek E, Albus M, Bormann M, Rietschel M, Lichtermann D, Weigel B, Lerer B, Maier W, Fimmers R, Propping P. 1997. Systematic search for susceptibility genes in bipolar affective disorder. Am J Hum Genet 61(Suppl):A288.

Nothen MM, Cichon S, Rohleder H, Hemmer S, Franzek E, Fritze J, Albus M, Borrmann-Hassenback M, Kreiner R, Weigelt B, Minges J, Lichtermann D, Maier W, Craddock N, Fimmers R, Holler T, Bauer MP, Rietschel M, Propping R. 1999. Evaluation of linkage of bipolar affective disorder to chromosome 18 in a sample of 57 German families. Mol Psychiatry 4:76.

Nurnberger JI Jr, Blehar MC, Kaufman CA, York-Cooler C, Simpson SG, Friedman JH, Severe JB, Malaspina D, Reich T, Miller M, Bowman E, DePaulo R, Cloninger R, Robinson G, Mildin S, Gershon E, Maxwell E, Guroff J, Kirch D, Wynne D, Berg K, Tsuang M, Faraone S, Pepple J, Ritz AL. 1994. Diagnostic interview for genetic studies. Arch Gen Psychiat 51:849-849.

Nurnberger JI Jr, Goldin LR, Gershon ES. 1994. Genetics of psychiatric disorders. In Winokur G, Clayton PJ (eds): The Medical Basis of Psychiatry, 2nd ed. Philadelphia: W.B. Saunders. p 459-492.

Rice JP, Goate A, Williams JT, Bierut L, Dorr D, Wu W, Shears S, Gopalakrishnan G, Edenberg HJ, Foroud T, Nurnberger J Jr, Gershon ES, Detera-Wadleigh SD, Goldin LR, Guroff JJ, McMahon FJ, Simpson S, MacKinnon D, McInnis M, Stine OC, DePaulo JR, Blehar MC, Reich T. 1997. Initial genome screen of the NIMH genetics initiative bipolar pedigrees: chromosomes 1, 6, 8, 10, and 12. Am J Med Genet 74:247253.

Risch N, Botstein D. 1996. A manic-depressive history. Nat Genet 12:351353. 
Schwab SG, Hallmayer J, Albus M, Lerer B, Hanses C, Kanyas K, Segman R, Borrman M, Dreikorn B, Lichtermann D, Rietschel M, Trixler M, Maier W, Wildenauer DB. 1998. Further evidence for a susceptibility locus on chromosome 10p14-p11 in 72 families with schizophrenia by nonparametric linkage analysis. Am J Med Genet 81:302-307.

Stine OC, Xu J, Koskela R, McMahon FJ, Gschwend M, Friddle C, Clark CD, McInnis MG, Simpson SG, Breschel TS, Vishio E, Riskin K, Feilotter H, Chen E, Shen S, Folstein S, Meyers D, Botstein D, Marr TG, DePaulo JR. 1995. Evidence for linkage of bipolar disorder to chromosome 18 with a parent-of-origin effect. Am J Hum Genet 57:1384-1394.

Stine OC, McMahon FJ, Chen L-S, Xu J, Meyers DA, MacKinnon DF, Simpson S, McInnis MG, Rice JP, Goate A, Reich T, Edenberg HJ,
Foroud T, Nurnberger JI Jr, Detera-Wadleigh SD, Goldin LR, Guroff J, Gershon ES, Blehar MC, DePaulo JR. 1997. Initial genome screen for bipolar disorder in the NIMH genetics initiative pedigrees: chromosomes 2, 11, 13, 14, and X. Am J Med Genet 74:263-269.

Straub RE, Lehner T, Luo Y, Loth JE, Shao W, Sharpe L, Alexander JR, Das K, Simon R, Fieve RR, Lerer B, Endicott J, Ott J, Gilliam CT, Baron M. 1994. A possible vulnerability locus for bipolar affective disorder on chromosome 21q22.3. Nat Genet 8:291-296.

Straub RE, MacLean CJ, Martin RB, Ma Y, Myakishev MV, Harris-Kerr C, Webb BT O’Neill A, Walsh D, Kendler KS. 1998. A schizophrenia locus may be located in region 10p15-p11. Am J Med Genet 81:296-301. 